\title{
On Divergent Tracks?: The ODA Policies of Korea and Japan in Comparison
}

\author{
HYUK-SANG SOHN ${ }^{* *}$
}

This paper aims to conduct a comparative study of South Korean and Japanese ODA policies. Korea has been generally considered to follow in Japan's footsteps in its ODA policies and in its institutional mechanisms. Are Korea's ODA programs simply modeled after those of Japan? This paper tries to test the validity of the hypothetical proposition that Korea's foreign assistance development policy was established based on the Japanese experience by conducting comparative inquiries on the philosophy and purpose, implementation system, and the regional allocation and sectoral distribution. After analyzing the two countries, this paper argues that even though Korea and Japan share many traits in ODA polices, Korea is more likely to pursue humanitarian objectives with its ODA rather than the politico-strategic goals of Japan.

Keyzords: ODA(Official Development Assistance), Korea, Japan, KOICA, JICA, Foreign Policy

*. This work was supported by a grant from the Kyung Hee University in 2007(KHU-20070703).

"The Graduate School of Public Policy and Civic Engagement, Kyung Hee University. 


\section{INTRODUCTION}

I

$\mathrm{n}$ recent years, public interest and activities concerning Official Development Assistance $(\mathrm{ODA})^{\prime}$ have been growing fast in South Korea.- The Korean government drew up the policy document, "General Guidelines for the Improvement of International Cooperation" and established the Committee for International Development Cooperation ${ }^{5}$ in 2005. In 2008, the Korean government also made a commitment that Korea would increase the ratio of its ODA/GNI, which currently places it at the lowest contribution level among OECD member countries, up to 0.25 percent of GNI by 2015. In January 2010, Korea was accepted as a new member of the Development Assistance Committee (DAC) of the OECD.

Korea's main legislative body, the National Assembly, also demonstrated its interest in the issue of forcign aid by passing a fundraising bill for ODA through establishing taxation on airline tickets in emulation of the French model in 2008 and also the International Development Cooperation Law in 2009. The active participation of NGOs in ODA monitoring also deserves our attention. Many NGOs, including Citizen's Coalition for Economic Justice and People's Solidarity for Participatory Democracy, have taken active roles in promoting public awareness concerning ODA and have worked to elicit participation on the part of ordinary citizens in the cause of international poverty eradication and the development of sustainable societies.

However, academic research has been lagging behind all of these developments and serious scholarly analyses concerning these new developments are actually difficult to find. Against this emerging backdrop, this paper aims to conduct a comparative study of Korean and Japanese ODA policies. South Korea has transformed itself from a recipient country to donor country in the 1980s. Such a transformation has been very rare which can be observed internationally. Korea has been generally considered to have been simply following in Japan's footsteps in its ODA policy and in its institutional mechanisms. Some have pointed out that the Korea International Cooperation Agency was modeled on its Japanese equivalent, the Japan International Cooperation Agency (JICA). However, Japanese ODA polices have not been well received at times by recipient countries due to the fact that Japan's assistance puts its priority on the economic interests of Japan rather than on improving the general welfare of individuals in aid recipient countries. Therefore, this paper tries to test the validity of the hypothetical proposition that South Korea's foreign assistance development policy was established based on the Japanese experience by conducting comparative studies on the policy objectives, implementation system, regional allocation and sectoral distribution of the two countries' ODA policies. Are South Korea's ODA programs simply modeled after those of Japan? Is South Korea, as a newly emerging donor country, attempting to search for new models for ODA programs that 
would be different from those of Japan? Are conventional theories of international relations any relevance in explaining the ODA programs of Korea and Japan? Though belated, comparative and systemic analyses of the ODA programs of South Korea and Japan require serious concern and attention in academia. This paper attempts to respond to these needs by making academic and theoretical contributions in relevant areas.

\section{POLICY OBJECTIVES OF ODA}

\section{Foreign Policy and Foreign Aid Policy}

Writing during the height of the Cold War, Morgenthau (1962, 301) opined that forcign aid is among the "real innovations which the modern age has introduced into the practice of foreign policy." If we are to understand the controversies that would emerge over foreign aid, and comprehend this important innovation in state relations, we need to understand why aid has been given in the past, how and why aid has differed from country to country given its purposes, and why and how these purposes have changed over time.

Why would states provide their own scarce public resources to promote, among other things, the well-being of people in other countries? According to the realist tradition, aid is, indeed, primarily a tool of hard-headed diplomacy. Realists allege that international relations are conducted in a Hobbesian state of nature in which national security and self-preservation become primary, if not exclusive, objectives. As a result, from this view foreign aid is perceived as only minimally-related to recipient economic development while the humanitarian needs of recipient countries are downplayed.

In contradistinction, the liberal tradition in international relations sees foreign aid as an instrument of states to cooperate in addressing the problems caused by interdependence and globalization. Growing amounts of aid have been channeled through international institutions and used to expand international "public goods," such as the controlling of the spread of infectious diseases worldwide and reducing environmental degradation.

Marxist scholars and "dependency" points of view have a different take on the purpose of foreign aid: They regard it as a tool used by the dominant states at the center of world capitalism, which helps them to control and exploit developing countries (Cockcroft, Frank, and Johnson 1972). They can illustrate many instances of foreign aid being tied to the funding of the export of goods and services from donor countries to recipient countries or in the securing of access to needed raw material imports for the benefit of these donor governments.

Through the lenses of "constructivism"-the newest tendency among international relations scholars-foreign aid has also been interpreted as the expression of a 
norm that has evolved in relations between states, that donor countries should provide assistance to poor countries to help the latter better the quality of lives of their peoples. Lumsdaine $(1993,3)$, the principal proponent of this view, argues that "economic foreign aid cannot be explained simply on the basis of donor states' political and economic interests, and that humanitarian concern in the donor countries has formed the main basis of support for aid." This support for aid was principally a response to world poverty which arose mainly from ethical and humane concern and, secondarily, from the belief that long-term peace and prosperity was possible only in a generous and just international order, where all could prosper. In this context of various theoretical approaches that the following question must be examined: What has been the profile of the purposes in Japanese and Korean ODA policies, and how have they evolved over time?

\section{Commercial and Politico-Strategic Purposes of Japanese ODA}

During most of the 1990s, Japan was the world's largest foreign aid donor. Meanwhile, Japanese ODA had played a prominent role in Japan's foreign policy. Wan (1995) defines Japan's ODA policy as a spending strategy. Wan also points out how " $\cdots$ in a sense, Japan purchased international recognition of its economic achievement" (Ibid., 91). Yet public recognition of Japan's ODA as a critical foreign policy tool seems low, and the effectiveness of this foreign policy is seen as uncertain (Yukiko 2007, 2). However, Hitoshi (2009, 12) states that financial and economic cooperation in the region will be largely market-driven, but security cooperation in East Asia will require strong political leadership. According to him, understanding Japanese ODA demands taking both an economic and a security focused point of view while considering the existing state of international affairs Japan has faced.

The work of Yukiko $(2004,2)$ analyzes the continuity of Japanese foreign aid policy and its features. He proposes that six different core ideas of Japan's economic policy can be identified: (1) The promoting of a self-help effort system, (2) the seeking of mutual interests between Japan and other Asian countries, (3) a state-led economy and long-term development plan, (4) efficient public-private cooperation, (5) utilizing foreign capital and technology, and (6) an aim to further the establishment of an Asian economic bloc.

Sawada (2010) proposes to describe some of the basic characteristics of Japanese ODA. Japan has provided a specifically high percentage of loans and aid for economically enhancing infrastructure and that Japan has allocated a large proportion of its aid to Asia, although its ODA portfolio to Sub-Sahara African countries has been increasing sharply.

Japanese aid has long been viewed as driven by commercial motives to facilitate the expansion of Japanese exports to recipient countries and to ensure Japanese 
access to needed raw material imports. Commerce certainly played a major role in recipient countries' allocation and use of Japanese assistance. According to Katada, two mainstream notions coalesced to characterize Japan's foreign aid policy: mercantilistic policies that emphasized economic interests and the humanitarian policies that corresponded with international standards (Katada 2002). Japan's traditional attitudes, that have put their economic interests first in the implementation of foreign aid policy, have allowed critics to charge that Japan was merely an 'economic animal' and would need to draw the ire and pressure from international society before improving its ODA programs. ${ }^{4}$

From their beginning, Japan's aid policies originated in war reparations the government was obliged to pay in the wake of its defeat in the Second World War. Some thirteen Asian countries were eligible for reparations payments at levels the Japanese government negotiated with each recipient. The total amount reached 2 billion USD in early 1960s. Reparations were used to finance projects requested by the recipient governments-which proved the beginnings of Japan's "request-based" approach to the selection of aid-funded projects. In theory, a government wishing to receive Japanese aid would identify a project for Japanese financing. But in reality, Japanese firms in developing countries would often identify projects and propose them to the government of the developing country, which would then "request" that the Japanese government fund them. Those same Japanese firms would later implement these projects once they were approved by Tokyo (Lancaster 2007).

Takamine $(2009,7)$ states that Japanese foreign policy has the complex policy objectives of Japanese ODA and also broader interests behind it. Particularly he addresses the fact that Japanese policymakers had commercial reasons for wanting to sustain stability in the case of China. Also, Japanese policy makers believed that a politically and economically chaotic China would be more likely to adopt aggressive foreign and military policies. In his 2009 paper he explains how important relations between political stability and economic interests joined with the goals to secure new markets and energy security.

Park (2003) divides the history of Japanese ODA policy into the two stages of the Cold War period and the Post-Cold War period. He characterizes the 1950 s and the 1960 s of the Cold War period as a 'strategic war compensation period' initiated with the goal of the promotion of export and import to support domestic development. This period, according to Park, was the incipient stage in the history of Japanese ODA development with its focus on war compensation. He then sees the 1960 s and 1970 s as a second stage defined by increase in the volume and the diversification of programs of Japanese ODA. The third stage which covers 1970 s and 1980 s was the period when the systematic consolidation of ODA programs was done aiming to secure Japan's economic interests through strategic ODA. He further understands the Post-Cold War period, beginning in 1989 , as "the period of maturation" when Japan's status as the 
world's leading donor country was used to exert its influence to gain more international political leverage.

Zhou (1991, 41), a Chinese scholar, maintains that the reasons behind Japan's expansion of its ODA were, (1) to strengthen its diplomacy to make up for its defective political power in the international arena that were caused by the limitations in its military build-up, (2) to secure its economic stability, as Japan heavily relied on other countries for its natural resources and energy, and (3) to acquire markets for its products outside of the US and also to establish a pan-Pacific economic cooperation zone with Japan as its leader.

According to revisions in Japan's ODA Charter in 2003 "the objective if Japan's ODA are to contribute to the peace and development of the international community, and thereby to help ensure Japan's own security and prosperity," (Japan's ODA Charter 2003, 1). "In order to achieve the objectives outlined above, Japan will carry out ODA even more strategically, in accordance with the following basic policies: (1) Supporting the self-help efforts of developing countries, (2) Perspective of Human Security. (3) Assurance of fairness, (4) Utilization of Japan's experience and expertise, and (5) Partncrship and collaboration with the international community." (Government of Japan 2003, 2).

Indeed, the basic principle of Japanese-style ODA is the support of self-help efforts (Watanabe 2005). Almost stated in the same manner as in the original ODA Charter, ${ }^{5}$ support for self-help efforts was accorded top priority in the new charter as follows:

The most important philosophy of Japan's ODA is to support the self-help efforts of developing countries based on good governance. by extending cooperation for their buman resoure dentopment. institution-building (induding derelopment of legal systems). and economic and social infrastructure building. which constitute the basis for these countries' development. Accordingly. Japan respects ounership by developing countries and places priority on their oun development strategies (Government of Japan 2003).

Along with economic and commercial purposes, Japan's strategic considerations deserve our attention, too. While Japan emerged as a potential economic rival to the United States in the 1980s, the US harshly criticized Japan for "free-riding" on the free trade and security efforts of others. In response, MOFA pledged to use ODA as a distinctive Japanese-US alliance contribution, and began to coordinate its ODA funding with US strategic initiatives.

\section{Diplomatic and Economic Purposes of Korean $O D A$}

In Korea, discussions around the issues of ideas and purposes of ODA policy have recently come to the fore. While governmental ministries such as the Ministry of Foreign Affairs and the Ministry of Finance and Economy have emphasized 
the principle of reciprocity, civil organizations have put priority on the humanitarian aspect of ODA programs. It is true that Korea's ODA programs have been considered to be a part of a foreign policy in which the fundamental goal has been to increase the nation's short-term economic interests by securing markets abroad and natural resources for Korean industries. However, there has been a slight change in this orientation, and attempts have been made in Korea to place its ODA in accordance with an international consensus which puts more importance on the humanitarian aspects of an ODA program.

The National Assembly of Korea passed a basic law on international development cooperation in December 2009 while there was as yet no consensus on the objectives and principles of an ODA policy in the Korean government. Yet we may outline the basic philosophy and objectives governing Korea's ODA from the laws related to the principal aid organizations such as the Korea International Cooperation Agency (KOICA) and the Economic Development Cooperation Fund (EDCF).

The KOICA Law, enacted in January 1991, describes the objectives of grants as the promotion of friendly ties and exchanges with developing countries. The EDCF Law, enacted in December 1986, describes the objectives of the Fund as assistance to the industrial development and economic stability of developing countries as well as the promotion of economic exchanges between Korea and these countries. The Internal Regulations of Handling the Grant Aid Operations of the Ministry of Foreign Affairs, enacted in October 1987. stipulates the objectives of grant aid as the promotion of diplomatic ties and trade, as well as humanitarian assistance.

Under these circumstances and after review of the relevant laws and regulations related to ODA and the experiences from the past implementation of ODA projects, the philosophy and objectives of Korea's ODA can be summarized as pursuing (a) a contribution to international peace and prosperity, (b) providing assistance to the economic development and stability of developing countries, (c) promoting friendly and cooperative relations and exchanges with developing countries, (d) and in providing humanitarian assistance (Government of Korea 1997, 35).

To set up the policy and administrative system for ODA distribution in a short time, the Korean government took much reference from the Japanese model. JICA was used as a good benchmarking case for formulating a "Korean-style aid model."

The Korean government took a positive stance towards foreign aid, but it was not seen as something separate from Korean domestic development. In an effort to manage the various new challenges surrounding the Korean economy in the late 1980s, the Korean government put greater emphasis on the promotion of economic cooperation with developing countries, as a means to reduce its own economic vulnerabilities and to strengthen its international competitiveness. 
Commercial considerations began to gain ground over political and diplomatic considerations as the raison d'être for Korea's ODA. In this regard, Korean policy began to resemble the Japanese approach. In fact, the Korean ODA as its structures and procedures were established was explicitly modeled on the Japanese experience. Korea's relative lack of experience as a "donor" country heightened the attractiveness of using other "donors" as models and Japan seemed the obvious choice (Kim and David 2005, 161).

Like Japan, Korea relied heavily on foreign trade as the principal engine of its economic growth in the $1970 \mathrm{~s}$ and 1980 s (trade as a proportion of total GNP varied between 56 and 68 percent between 1977 and 1987), and it continued to remain a critical factor for its sustained development. Furthermore, Korea's exports were heavily concentrated in a few industrial markets, making Korea externally vulnerable to protectionism. So, in an attempt to diversify its export markets and to reduce its dependence on existing major trading partners, such as the United States, Korea began to target developing countries as potential markets. Korean foreign direct investment (FDI) in development countries, and in Asia in particular, increased from 46 percent of total FDI in 1987 to 52 percent in 1992 (Government of Koreat 1993, 153).

Korea's explicit and implicit intention in its use of ODA as a tool for its own development in the context of its economic policies is well-reflected in its use of the term "economic cooperation," which refers to all external economic exchange or relations; but is in practice used in documents interchangeably with descriptions of providing "aid" (Government of Korea 1989). The term "economic cooperation" covered all efforts to promote capital flows from developing countries (although the DAC definition excludes these from ODA). Indeed, the Korean government sometimes explicitly justifies its preference for "economic cooperation" over "ODA" as it views itself as a latecomer "donor" country (Kim 1990, 12).

Ko, Kim, and Hong $(2010,111)$ state that through Korean Foreign Policies such as strengthening ODA and PKO (Peacekeeping Operations), Korea as a member of DAC takes the lead in abiding by international norms first and the sustainability of Korean ODA is maintained by seeking to meet the reciprocal national interests of the donor country and the recipient country. They emphasize that Korean Foreign Policy would be best served by following a communal development strategy based on international support and cooperation (Cheongwadae 2009). The Ministry of Foreign Affairs and Trade sets the goal of Korea's ODA to contribute to poverty reduction and sustainable development. ${ }^{6}$

Lumsdaine and Schopf (2007. 222) state that historically, strong support for aid has been linked primarily to humanitarian motives in Korea. They argue that Korea did not emphasize these rationales for aid very strongly during the late 1980s and 1990s, But lately various features of the Korean situation have improved to allow the Korean government to increase spending on foreign assistance 
and adopt a policy more closely in accordance with a humanitarian long-term vision (247). In addition. They analyze a recent rise in voluntarism, the expanded political influence of NGOs, and strong popular support for assistance to the poor, both at home and abroad, signal a shift in civic values, and can account for the current increase in humanitarian aid to North Korea and the developing world (221).

Since 1994, Korea's UDA policy has entered a period of drift and was implemented without reference to any fundamental ideas or towards a particularly clear orientation. The international standard has become to refer to the list of recipient countries drawn up by DAC of OECD based on GNI of each country. Though one can find the group of the 49 poorest countries in this list, which is normally given priority in terms of aid, the top 10 predominant recipient countries for foreign assistance from KOICA include relatively better off countries such as the Philippines, China, and Thailand, while giving less assistance to the neediest countries, like Cambodia and Laos.

\section{ODA GOVERNMENTAL ORGANIZATIONS}

\section{Japan's Foreign Aid Implementation System}

Japan has the most complex and diversified ODA system among DAC member countries and it is thus estimated that there can be difficulties in the coordination of such diverse ODA activities. The Committee for Diplomacy and Defense within the National Diet takes part in dealing with ODA-related issues. There is also an 'ODA Innovation Task Team' in the dominant Liberal Democratic Party. In addition to these organizations, there also exist numerous consultative agencies such as 'Strategic ODA,' 'Council for ODA Reform,' and 'Strategic Board for ODA.' Though these organizations contribute to promoting public understanding of ODA-related issues and the transparency of procedures around ODA, these organizations may have negative effects in general because they complicate the deliberation process and the results of discussions are not clearly stated. A "behind closed doors" deliberative process runs throughout the system.

The major players in the government are three ministries: the Ministry of Foreign Affairs (MOFA), the Ministry of Finance (MOF), and the Ministry of Economy, Trade and Industry (METI), which has a core coordination role; and two agencies, the Japan International Cooperation Agency (JICA) and the Japan Bank for International Cooperation (JBIC), play major roles in implementation (DAC/OECD peer review report 2003).

MOFA is responsible for formulating ODA policy and coordinating relevant agencies, the administration of most grants, ${ }^{7}$ administrative oversight of the JICA and JBIC/OECD and coordinates UN operations. The Minister coordinates 
the operational responsibilities of 10 different foreign affairs bureaus, headed by their respective Director Generals. The Economic Cooperation Bureau (ECB), and to a lesser extent the Multilateral Cooperation Department (humanitarian assistance, and international organizations such as UNCHR and UNICEF), the Economic Affairs Bureau (international organizations such as WTO), and the geographic bureaus (regional development conferences such as TICAD) are responsible for development-related operations, including grant assistance and parts of the UN's ODA portfolio. ECB leads the ODA policy formulation and interagency coordination, including in the annual ODA budget process. In system terms, this places the ECB in the forefront of ministry interface with the other implementation agencies and ministries.

The location of the ECB's role for development cooperation within MOFA offers opportunities for greater policy coherence among the various aspects of Japanese foreign policy, although development cooperation is only one part of overall ministry priorities. ECB (and, therefore, development cooperation) competes with the other nine director generals for the attention of the minister, who is generally the main voice of development cooperation on the cabinet. Current international organizational reform is intended to strengthen ECB's ability to coordinate with the development agencies, although insufficient staffing has continued to be a problem.

JICA is the largest ODA involved institution in terms of the size of the staff and is the only institution to be entirely specialized in development cooperation. It has multiple responsibilities, including personnel and organizational management, and is subject to organizational performance evaluations and various disclosure obligations. JICA operates according to mid-term (3-5 years) objectives defined by MOFA, around which it prepares a mid-term plan and subsequent annual plans. The initial JICA mid-term planning is currently focused on increasing efficiency ("reduce unit costs of major forms of input by 10 percent on average over the next three years") and improving the quality of services (e.g., shifting to a field-oriented approach, reinforcing project formulation, implementing peacebuilding operations, promoting public participation, and mobilizing non-governmental resources). Organizational evaluations of the JICA are made by the Evaluation Committee of MOFA.

A second, somewhat smaller implementation agency (but not in terms of its funding responsibility), is the JBIC. It was formed in 1999 as the result of a merger of the former OECF and JEXIM. JBIC now believes that this organizational merger has reduced transaction costs through the use of common systems and closer collaboration on important issues like the relationship between very different development and commercial operations. JBIC constructed an administrative firewall between the two functions to address this concern which left it with a bifurcated organizational structure composed of the Overseas Economic Cooperation Operations (OECO) group and that of International Financial 
Operations (IFO). OECO's role (ODA loans, private sector investment finance, studies) is essentially ODA funded, while that of IFO is not. To accomplish their different mandates, the two sides of JBIC report administratively to two different entities (MOFA and MOF, respectively) and maintain largely different sets of procedures. About one-third of JBIC funding is allocated to the OECO, and approximately one-third of its staff works there. JBIC has 27 field offices, most of which have some type of OECO functions.

The MOF has a role in development cooperation and maintains a specialized analytical capacity (sector strategies, debt issues, macro-economics) that could prove helpful in supplementing other agency capacities in these areas as the ODA network becomes better coordinated over time. As with MOFA, the organizational focus is on development cooperation. Some 67 staff members in the International Bureau are engaged in ODA related issues. The MOF addresses issues of development in the IMF, the World Bank and the regional development banks.

On October 1, 2008 Japan International Cooperation Agency (JICA), integrated with the Japanese yen loan department of the Japan Bank for International Cooperation (JBIC) and a part of the grant aid operations of the Ministry of Foreign Affairs (MOFA). The integration is part of the Japanese government's aim to rationalize its aid agencies and improve efficiency. JICA's new structure has three major assistance tools: Technical Cooperation, ODA Loans and Grant Aid (Figure 1). The success of new experiment of the JICA's merge with JBIC is yet to be seen. However, it gives a strong impetus for Korea's integrating reform of the fragmented implementing institutions, which will be discussed in the next section.

\section{Korea's Foreign Aid Implementation System}

Korea has a decentralized ODA administrative system where more than twenty ministries and agencies are involved (Figure 1). Among them, the Ministry of Foreign Affairs and Trade (MOFAT) and the Ministry of Strategy and Finance (MOSF) are the key organizations. MOFAT is supervising KOICA which is in charge of bilateral grants, while MOSF is controlling the Export-Import Bank of Korea (KOREAEXIM) that manages bilateral loan lending program through the Economic Development Cooperation Fund (EDCF). ${ }^{x}$

Multilateral assistance, referring to foreign aid, delivered through international organizations is divided into contributions to the UN system and subscriptions to international financial institutions such as the IMF and the Asian Development Bank (ADB). Contributions to the UN and its specialized agencies are implemented by MOFAT. Financial subscriptions to international financial institutions are managed by MOSF. 
Figure 1. Aidadministration in Japan and Korea

(a) Japan

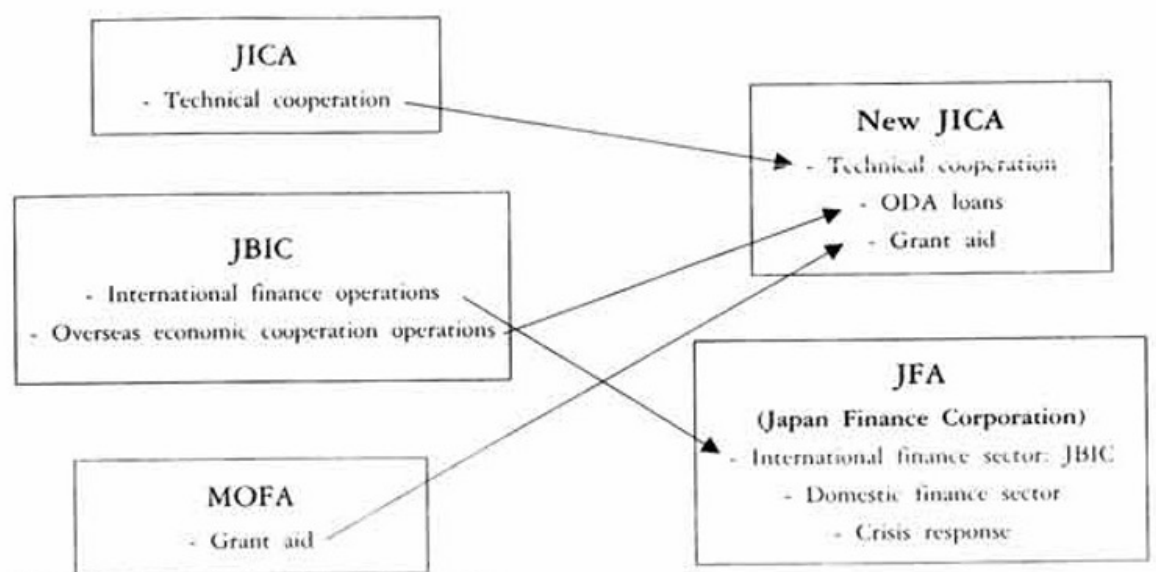

SOURCE: JICA Special Report June 2009

(b) Korea

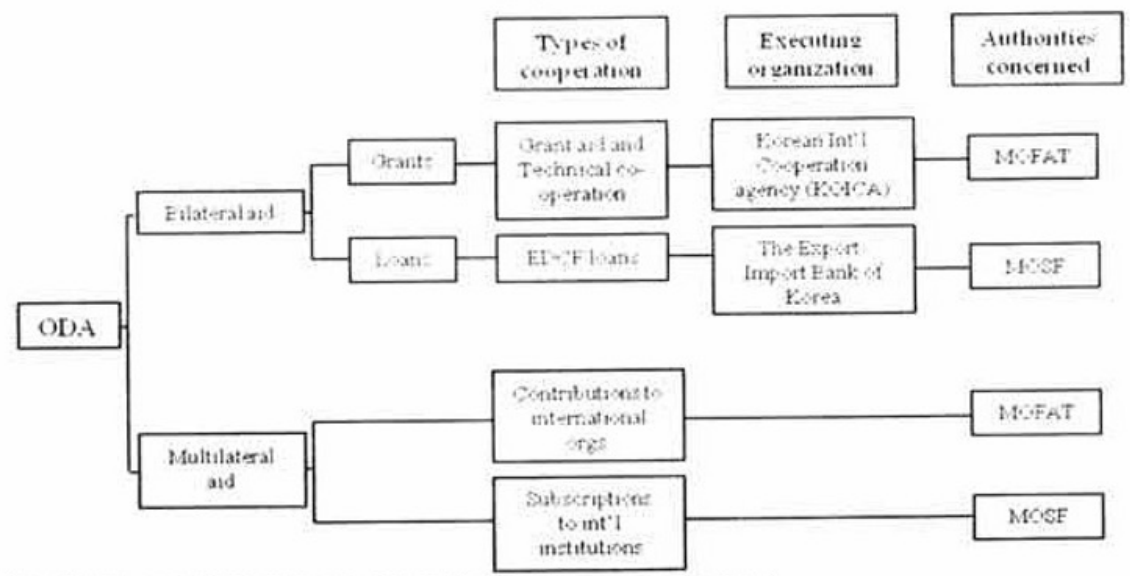

SOURCE: OECD/DAC Special Review of Republic of Korea 2008.

KOICA was explicitly modeled on JICA. Both agencies (which are technically non-governmental entities) and implement similar functions under the authority of their respective foreign ministries; each government's foreign ministry provides guidance and receives reports on aid implementation (Kim and Seddon 2005, 170). The Board of Executive Direction of KOICA comprises a chairman (the president of KOICA), three KOICA executive directors, and six directors-general (from the Prime Minister's Office and from the five ministries-the MOFAT, 
MOSF, the Ministry of Construction and Transport, and the Ministry of Labor -which have vested interests in KOICA programs).

\section{AID VOLUME AND QUALITY}

\section{Japan}

\section{(1) Amount of Japanese ODA}

Japan made impressive progress in terms of the amount of its ODA, reaching the top of the list of the donor countries in 1989, with the US ranking second. Since the 1970s, the total amount of Japanese ODA started to increase at a very rapid rate until 1996, when the amount started to decrease. The reasons that the total amount of Japanese ODA continued to decrease for more than 10 years since the late 1990 s might be ascribed to Japan's economic depression which occurred during that period, and also to the Asian financial crisis of the late 1990s.

TABI.E 1. NeT ODA BY MAJOR DAC COUNTRIES (USD million)

\begin{tabular}{|c|c|c|c|c|c|c|c|c|c|c|c|c|}
\hline & & $\begin{array}{l}1989 . \\
1900\end{array}$ & $\begin{array}{l}1904 . \\
1905\end{array}$ & 2001 & 20012 & 20035 & $3(6) i$ & 2005 & 20060 & $2000^{-}$ & 2008 & $2(4) 5$ \\
\hline \multicolumn{13}{|c|}{ (Average) i Average) } \\
\hline \multirow{2}{*}{ Denmark } & Net ODA & 1.504 & 1.534 & 1.634 & 1.643 & 1.7 .88 & 2.057 & $2.1(6)$ & 2.236 & 2.562 & 2.803 & 2.804 \\
\hline & $\%$ of GNI & 694 & 0.4 & 1.03 & 0.96 & $0 . x_{i}$ & 1).85 & 0.81 & 0.80 & 0.81 & 0.82 & $0,8 \mathrm{~s}$ \\
\hline \multirow{2}{*}{ France } & Net OB)A & 6. 184 & 8,455 & 1.198 & $5.4 \mathrm{se}$ & 7,253 & $x+y^{-2}$ & 10.626 & 10.601 & $9.8 \times-i$ & 10,918 & 12,130 \\
\hline & $\%$ of GNI & 0.60 & $0.5 \mathrm{~s}$ & 0.31 & 0.37 & 0.40 & 0.71 & 0.47 & 0.47 & 0.39 & 0.39 & 0.46 \\
\hline \multirow{2}{*}{ Germany } & Net ODA & 5.634 & 7.171 & $4.9 \%$ & 5.324 & $6,78 i$ & 7.534 & 10.082 & 10.435 & 12,291 & 13.981 & 11.982 \\
\hline & 4 of GNI & 0.42 & 0.32 & 0.27 & 0.27 & 0.28 & 0.28 & 0.36 & 0.36 & 0.37 & 0.38 & 0,35 \\
\hline \multirow{2}{*}{ Japan } & Net ODA & 9.017 & 13.86 .1 & 9.817 & $9.2 \times 3$ & $8.8 \times 11$ & 8.923 & 15.147 & 11,187 & 7.679 & 9.579 & 9.480 \\
\hline & w of GNI & 0.31 & 0.28 & 0.23 & 0.25 & 0.20 & 0.19 & $0.2 \mathrm{~s}$ & 0.25 & 0.17 & 0.18 & 0.18 \\
\hline \multirow{2}{*}{ Sweden } & Net ODA & 1.903 & 1.762 & $1.6(x)$ & 2,012 & 2.400 & 2,722 & 3.362 & 3.955 & 4.339 & 4.732 & 4.546 \\
\hline & $\%$ of GNI & 0.93 & 0.86 & 0.77 & 0.81 & 0.79 & 0.78 & 0.94 & 1.02 & 0.93 & 0.98 & 1.12 \\
\hline \multirow{2}{*}{ USA } & Net ODA & 9.536 & 8.647 & 11.429 & 13.290 & 16,320 & 19.705 & 27.622 & 23.532 & 21.787 & 26,842 & 28.665 \\
\hline & \% of GNI & 0.18 & 0,12 & 0.11 & 0.13 & 0.15 & 0.17 & 0.22 & 0.18 & 0.16 & 0.18 & 0.2 \\
\hline \multirow{2}{*}{ Total } & & 49.232 & 58.800 & 52.135 & 58.292 & 69.085 & 79.410 & 106,777 & 104.368 & 103.485 & 121.485 & 119.575 \\
\hline & DRe & 0.32 & 0.28 & 0.32 & (1).23 & 0.25 & 0.26 & 0.33 & 0.31 & 0.28 & 0.30 & 0.31 \\
\hline
\end{tabular}

SOURCE: OECD International Development Statistics Online DB.

The growth and decline of Japan as an ODA donor roughly paralleled its trajectory as an economic superpower. Japan's emergence as an industrialized economy can be seen as linked with its cooperation with other advanced countries, 
and included the monitoring and coordination of its members' bilateral ODA programs through DAC. After it joined the OECD in 1964, Japan increased its ODA spending roughly in line with its GDP growth, and by 1973 it had ascended to become the fourth-ranked OECD donor.

Japanese ODA net disbursements peaked at 15.3 billion USD in 1999, but afterward steadily dropped to 9.8 billion USD in 20()1, falling below the US figure of 11.4 billion USD in that year. As shown in Table $i$, Japan's 0.3 percent of ODC/GNI ratio at 1990 dropped by more than one-third to 0.17 percent at 2009. After losing its number one status in 2001, Japan's net ODA in constant dollars declined another 1.2 percent in 2002, while DAC Total net outlays increased 7.2 percent (Arase 2005, 3). However, in 2005 Japanese ODA recovered to the level of 1999's spending by recording 13.1 billion USD in ODA on a net disbursement basis, enabling it to remain as the world's second largest donor.

\section{(2) Japanese ODA quality}

Until recently, Japan has been evaluated as the DAC's leader in terms of the absolute quantity of ODA provided, but the picture is complicated if one uses standard DAC methods for measuring a member's ODA effort. Although Japan did top the list of DAC donors in dollar spending for many years, its effort in relation to its national income has always remained below the DAC median, and well below the target of 0.7 percent of GDP set back in 1970) by the UN and reaffirmed by all DAC members in 2002.

With the remainder given to multilateral international development institutions and agencies, Japan has devoted $70-75$ percent of its total ODA over the past decade to bilateral programs. Japan organizes its bilateral ODA into grant aid and loan aid categories. This grant aid category is further divided and categorized into general grant aid (i.e., mainly capital-intensive projects in social and cultural sectors directly administered by MOFA), and technical cooperation (i.e., knowledge transfer through human exchange and related equipment transfers that is mainly administered by JICA). The share of the grant aid category in total bilateral ODA has grown over time in response to international pressure to improve concessionality 9 and raise the impact of Japanese ODA in poverty reduction strategies. Within the grant aid category, the emphasis has shifted steadily toward technical cooperation. In 1970, this accounted for 18 percent of grant aid spending, but its share steadily grew to 41 percent by 2002. Nevertheless, Japan has given consistently less priority to technical cooperation as a share of total ODA was 19 percent compared to 28 percent for all DAC members.

The other bilateral category is loan aid, which consists of engineering and construction loans, mainly for economic and industrial infrastructure administered by JBIC. These loans used to be the core component of Japan's bilateral aid. 
They made up 67 percent of total bilateral ODA in 1970, but on a net disbursement basis the loan share has decreased gradually to 35 percent in 2002, and the repayment terms have been softened considerably. Despite this change, loans have been, and continue to be, an outstanding feature of Japan's ODA (Arase 2005, 5). The aggregate data for all DAC members shows that in 2004 the loan share of total bilateral ODA was about 10 percent, compared to 34 percent in Japan's bilateral ODA.

Over the years the terms of Japan's bilateral ODA have improved, but they remain less concessional than most other DAC donors, due to the heavy reliance on loans.

One of the primary reasons for Japan to focus on loans was mostly due to its own experience of having borrowed credit from the World Bank for its post-war reconstruction. It considers that loans promote "self-help efforts" that respect more ownership by the recipient country as opposed to grants that have no obligation of repayment. Loans could also finance large scale infrastructure projects which would be more difficult to justify with grants. Furthermore, although the loans are substantially concessional (over 70 percent grant element), they would be of less burden to Japanese tax payers. Loan projects also tend to comply with the priorities of the recipient governments, as they are reviewed and selected by them, and are not solely prioritized by the Japanese grant agency. For example, in Indonesia the Parliament has to approve loans it is responsible to repay, whereas it does not have the sime approval process for grants (OECD/DAC Peer Review of Japan 2003, 22).

There has been long standing international criticism of Japanese ODA on the grounds that it has been too reliant on bilateral loans in pursuit of Japan's own economic interests. During the decade 1961-71, the share of Japanese bilateral loans relative to grants was generally over 60 percent (Rix 1980, 32) and between 1977 and 1979 it averaged 72 percent; but this amount has been progressively declining. From 1986 to 1988, it averaged 56 percent, and from 1996 to 1998 , 33 percent (Kim 1990; Government of Korea 1997; Government of Korea 1998; Government of Korea 1999; Kim and Seddon 2005).

According to DAC standards, ODA loans are generally untied (Table 2). This was commended since untied aid is normally considered to be more cost effective and allows for greater partner country ownership of the target aid project and for a harmonization of donor procedures. However, the tying conditions of Japanese ODA were very often criticized by the international ODA community. For example, Japan established a short-term tied Special Yen Loan facility from 1999 to 2002 aiming at helping the countries that were affected by the Asian crisis (OECD 2003, 23). Incidental to this, though a source of criticism for the Japanese, was that these loans were often used to purchase Japanese goods and service and, therefore, were designed to simultaneously assist the ailing Japanese economy at that time. They were mainly used in three priority areas: the establishment 
of infrastructure for an improved flow of goods (roads, ports, airports, bridges, railways), the strengthening of the production base (power stations, irrigation, natural gas pipelines, water supply), and counter-measures against large-scale disasters.

TABle 2. Reporting of the Tying States of Bllateral. ODA in 2007

\begin{tabular}{|c|c|c|c|c|}
\hline \multicolumn{5}{|c|}{ Total ODA } \\
\hline & Total USD million & Untied \% & Tied $\%$ & Not reported \% \\
\hline Australia & 1,620 & 96 & 4 & .. \\
\hline Austria & 1,344 & 78 & 22 & .. \\
\hline Belgium & 1.531 & 96 & 4 & .. \\
\hline Canada & 3.101 & 74 & 20 & 6 \\
\hline Denmark & 1.357 & 96 & 4 &.. \\
\hline Finland & 608 & 92 & 8 &.. \\
\hline France & 7.871 & 90 & 9 & 1 \\
\hline Germany & 9.366 & 75 & 18 & 7 \\
\hline Greece & $22-1$ & 1.1 & 11 & 75 \\
\hline Ireland & 791 & 100 & $\ldots$ & $\approx$ \\
\hline Italy & 1.397 & 54 & 36 & 11 \\
\hline Japan & 11.834 & 80 & 4 & 16 \\
\hline Luxembourg & 237 & 100 & $\ldots$ & $*$ \\
\hline Netherlands & 4.535 & 82 & 18 & *. \\
\hline New Zealand & 259 & 84 & 16 & .. \\
\hline Norway & 2,711 & 100 & .. & .. \\
\hline Portugal & 591 & 38 & 6 & 56 \\
\hline Spain & 3.658 & 65 & 30 & $s$ \\
\hline Sweden & 2,113 & 95 & .. & $s$ \\
\hline Switzerland & 1,415 & 100 & ... & .. \\
\hline United Kingdom & 5.681 & 100 & $\ldots$ &.. \\
\hline United States & 23,330 & 67 & 33 & .. \\
\hline Total & 85.595 & 79 & 17 & 4 \\
\hline
\end{tabular}

SOURCE: OECD Implementation of the 2001 DAC Recommendation on Untying ODA to the LDCs 2009 Review (2009).

\section{Korea}

\section{(1) Amount of Korean foreign aid}

Though the amount of Korean ODA has witnessed a remarkable increase 
from 60 million USD in 1991 to 803 million USD in 2008, Korea's ODA/GNI ratio remains at less than 0.10 percent, which is very small relative to the DAC average of 0.25 percent. At the ASEAN-Republic of Korea Commemorative Summit held on Jeju Island in June 2009, the Korean government pledged to double the volume of its ODA for poverty reduction and sustainable socioeconomic development to 400 million USD by 2015 for Asian countries alone. The government aiso announced that it would provide an additional 200 million USD through the East Asia Climate Partnership scheme and would meet ODA/GNI targets of 0.15 percent by 2012 and 0.25 percent by 2015 . The UN's recommendation, for reference, is for countries to increase their ODA/GNI ratio up to 0.5 percent by 2010 and to 0.7 percent by 2015 .

The history of Korea's ODA dates back to 1963, when Korea first received trainees from developing countries, with financial support from USAID. Korea began to fund foreign trainees itself in 1965 and to dispatch its own experts to developing countries in 1967. The government started the overseas placement of medical doctors in 1968, and the first project-type technical cooperation was initiated in 1969. During this period, Korea was itself in the early stages of economic development under its First Five-Year Plan (1962-1966) and remained a principal recipient of ODA from developed countries, primarily the United States. In 1966, Korea's per capita GNP was only 125 USD in current prices, and even by 1969 was only 210 USD (Kim and Seddon 2005, 153).

During the period of 1960 to 1989 , Korea moved from being the world's thirty-seventh to its fifteenth-largest economy and from the fifty-first-largest to the twelfth-largest trading nation; and in terms of per capita income, it went from eighty-third to fortieth. At this juncture, Korea's aid program developed as its economy expanded through the 1980s. Even at the end of the decade, however, Korea's ODA remained relatively small in its ODA/GNP ratio. Korea's ODA in 1990 (and in 2000) was equivalent to 0.04 percent of GNP, well below any of the other DAC countries (even Ireland which was runner up to be lowest with 0.16 percent) and far below the DAC average of 0.33 percent (Ibid., 155; Ko and Lee 2008).

As can be seen in Table 3, in 1998 Korea's ODA stood at 182.7 million USD, having risen at an annual rate of 19.5 percent on a USD basis and 32.5 percent on a Korean currency basis over the eight years from 1991 to 1998. In 1999 it rose to 317.5 million USD, 5.5 times more than in 1991 ( 57.5 million USD), due to an exceptional increase in subscriptions (126 million USD) to the International Bank for Reconstruction and Development (IBRD) and international development assistance (IDA) in 1999. The DAC member countries whose ODA volumes were lower than that of Korea in 1999 included Greece, Ireland, Luxembourg, New Zealand, and Portugal. However, Korea's ODA/GDP ratio lagged well behind international standards. The target for ODA as a percentage of GNP is set at 0.7 percent by the UN. In 1999, DAC member countries 
that met this target were Denmark, Netherlands, Norway, and Sweden. The DAC average was 0.24 percent, with the US at the lowest ratio at 0.1 percent of GNP. Korea's ODA/GNP ratio ranged from 0.02 to 0.08 percent during 1991-1999; and in 2000 it was at 0.04 percent. Korea's per capita ODA contribution in.1999 amounted to 6.9 USD, while those of DAC nations averaged 67.1 USD.

Table 3. Treni) of Korea's ODA (USD million)

\begin{tabular}{|c|c|c|c|c|c|c|c|c|c|c|c|c|c|c|}
\hline & 1996 & 1497 & 1908 & 1999 & 2000 & 2001 & 2002 & 2003 & 2004 & 2005 & 2006 & 2007 & 20018 & $30(4)$ \\
\hline $\mathrm{OBA}$ & 159.2 & 185.6 & 182.7 & 317.5 & 2121 & $261^{-}$ & 278.8 & 26.1 .7 & 423.3 & 752.3 & 446.7 & 699.1 & 803.0 & 815.8 \\
\hline Bilateral & 1233 & 111.3 & 121.7 & 131.8 & 131.2 & 171.5 & 206.8 & 2152 & 330.8 & +63.3 & 365.6 & (1)3.5 & $539.9^{\circ}$ & 580.27 \\
\hline Grants & 53.4 & 54.8 & 57.2 & 39.0 & +7.8 & 53.0 & 6627 & 1 is.5 & 212.1 & $51 \times 0$ & 248.5 & 361.5 & 360.3 & 366.14 \\
\hline Lstans & (a) $)$ & 56.6 & $x+5$ & $92: 1$ & $\times 3.1$ & 1186 & 1601 & $(m)^{-}$ & 118.7 & 1 is. & $11-1$ & 162 & 1906 & 21,13 \\
\hline Multilater.al & is. $\mathrm{s}$ & $-1,3$ & $5 \times 11$ & $1 \times 6, \mid$ & soy & 45,1 & +20 & $120^{-}$ & 22,6 & 28901 & 811 & 20156 & 263.1. & 235.53 \\
\hline ODA.GNI I6) & 005 & 0018 & 005 & $00^{-}$ & 001 & 0,106 & 10.05 & 10.06 & 0,06, & 0.16 & 0.65 & $666^{7}$ & 0.05 & 0.1 \\
\hline
\end{tabular}

\section{(2) Korean ODA quality}

DAC's annual report compares ODA quality using the level of grant share, grant element, and tying status as yardsticks. With the exception of grant element, the quality of Korea's ODA is very low in comparison with that of DAC member countries (Ibid., 174; Ko and Lee 2008).

Grant share refers to the percentage of grants including grant aid, technical cooperation, and contribution payments to international agencies. The grant share of Korea's ODA in 1991-1999 ranged from 34 to 56 percent with an average of 45 percent. The average grant share of total and bilateral ODA in 1998-1999 recorded at 36 percent and 30 percent respectively, while DAC averages were at 81 percent and 73 percent. With reference to the annual average growth of ODA during 1991-1998, bilateral grants recorded only 7 percent growth while bilateral concessional loans went up by 65 percent and multilateral assistance by 23 percent (Ibid., 174).

Grant volume from 1991 to 1997 had increased continuously. However due to the foreign currency crisis, it went down for the next two years. From 2000 till the present, grants have soared.

The ODA volume in 2005 jumped 78 percent over 2004. 463.3 million USD given through bilateral aid, which is a 40 percent increase from the previous year and amounts to 62 percent of the total ODA volumc. However, the sudden increase in the aid volume in 2005 should be seen as exceptional due to unexpected circumstances such as aid to Iraq and new contributions to the International development Bank (IBD) and the World Bank (Kwon 2006, 135). 
TABle 4. Ratio of Bilateral. Grants Versus loANS (USD million)

\begin{tabular}{|c|c|c|c|c|c|c|c|c|c|c|c|c|}
\hline & 1991 & 1992 & 1995 & 1996 & 2000 & 2001 & 2004 & 2005 & 2006 & 2007 & 2008 & 2009 \\
\hline Grants (A) & 25.0 & 31.0 & 50.1 & 53.4 & 47.8 & 53.0 & 212.1 & 318.0 & 248.5 & 361.3 & 369.3 & 366.14 \\
\hline Loans & 6.5 & 14.2 & 21,4 & 69.9 & 83.4 & 118.6 & 118.7 & 145.3 & 117.1 & 132.2 & 170.6 & 214.13 \\
\hline Total (B) & 31.5 & 452 & 715 & 1233 & 1312 & 1716 & 3308 & 4633 & 3656 & 4935 & 5399 & 58077 \\
\hline$(\mathrm{A} / \mathrm{B}): \%$ & 79.4 & 68.5 & 70.1 & 43.3 & 36.4 & 30.8 & 64.1 & 68.7 & 68.0 & 73.2 & 68.4 & 63.1 \\
\hline
\end{tabular}

SOURCE: revised from Kim and Seddon 2005; KOREA EXIM.

The Korean government put greater and increasing priority to loans in allocating its bilateral ODA (Table 4). This is basically for at least two reasons: first, it is easier to expand loans than grants and second, the EDCF loans, which support recipient countries' commodity imports and large development projects. are expected to increase business opportunities for Korean companies through tying conditions.

TABIE 5, KorES BHATERA. ODA USF1) BY (t'N)TIEL TIPI

\begin{tabular}{cccccccc}
\hline & \multicolumn{2}{c}{ Untied } & \multicolumn{2}{c}{ partially unticd } & \multicolumn{2}{c}{ Tied } & Total \\
\hline & USD million & Percent & USD million & percent & USD million & percent \\
\hline 2000 & 2 & 0.8 & 1 & 1.8 & 223 & 97.3 & 229 \\
\hline 2001 & 2 & 1.5 & 6 & $4 .+$ & 137 & 9.5 & 1.45 \\
\hline 2002 & 3 & 1.6 & 19 & 8.9 & 192 & 89.5 & 215 \\
\hline 2003 & 7 & 2.5 & 45 & 16.9 & 215 & 80.6 & 267 \\
\hline 2004 & 17 & 4.2 & 62 & 15.0 & 331 & 80.8 & 410 \\
\hline 2005 & 14 & 2.6 & 89 & 16.0 & 452 & 81.4 & 555 \\
\hline 2006 & 10 & 1.9 & 98 & 18.6 & 417 & 79.5 & 525 \\
\hline 2007 & 200 & 24.7 & 95 & 11.7 & 514 & 63.5 & 809 \\
\hline 2008 & 429 & 35.8 & 90 & 7.5 & 679 & 56.7 & 1198 \\
\hline
\end{tabular}

SOURCE: OECD International Development Statistics Online DB.

Grant element is one of the measures of "concessionality," or the "softness" of the terms under which ODA is provided. Korea's average grant element during 1998-1999 was 63 percent, in comparison with 68 percent for other DAC member countries. "Tying status"-which indicates how much of ODA must go to purchase the goods and services of the "donor" country or is to be used for a specific project, product, or sector-is another measure. In 1998, the untied share of Korea's bilateral ODA averaged only 0.8 percent; the partially untied aid at 5.4 percent and the tied 93.8 percent. These figures are in sharp contrast with those of all other DAC members whose untied share averaged 
83.8 percent. The Arrangement on Guidelines for Officially Supported Export Credits (OECD) limits the use of tied aid for projects that should be financed commercially. When Korea joined the OECD in December 1996, it was on condition that the ongoing 53 loan projects would be exempted from this rule (Kim and Seddon 2005, 175).

\section{REGIONAL ALLOCATION}

\section{Japan}

In substance, Japan has a regional perspective and has recently carried out various initiatives within Asia. As suggested would be the case in Japan's ODA Charter, the majority went to Asia at 70 percent in 2001 (Total DAC 39 percent), 11 percent to the Americas (Total DAC 15 percent), and 14 percent to Africa (Total DAC 33 percent), of which 10 percent was to Sub Sahara Africa (Total DAC 26 percent). In 2002, disbursements to Asia increased to 74 percent, of which most went to the Far East. However, over the long term, this constitutes a reduction from 83 percent in 1976. With 6.7 billion USD in aid to Asia, Japan is still by far the largest donor, providing almost half of all DAC ODA to the region. Although the proportion of allocation to SSA is relatively small in real terms and has not increased despite the TICAD meetings, with its 722 million USD, Japan was the fourth largest bilateral donor to the sub-region in 2001 (OECD 2003, 24).

In order to find out how well its members are targeting poverty and addressing broad humanitarian issues, DAC measures the distribution of ODA by geographic region, functional sector, and the income level of recipient countries (Arase 2005 , 7). A defining feature of Japan's ODA is its geographic distribution, which has heavily favored Asia ever since its inception.

TABle 6. Regional. Distribution of ODA by JAPAN

\begin{tabular}{ccccccc}
\hline & $1994-1995$ & $1999-2000$ & $2004-2005$ & 2006 & 2007 & 2008 \\
\hline Sub-Saharan Africa & 11.6 & 9.3 & 15.2 & 26 & 19 & 11 \\
\hline South and Central Asia & 20.5 & 17.4 & 13.7 & 15 & 16 & 24 \\
\hline Other Asia and Oceania & 49.7 & 55.4 & 40.7 & 39 & 44 & 35 \\
\hline Middle East and North Africa & 6.8 & 6.3 & 19.3 & 10 & 13 & 19 \\
\hline Europe & 0.8 & 2.1 & 1.8 & 2 & 3 & 4 \\
\hline Latin America and Caribbean & 10.6 & 9.5 & 9.3 & 7 & 6 & 6 \\
\hline SOURCE: OECD International Development
\end{tabular}

The majority of Japanese ODA goes to Asian countries, which might seem 
natural as they are Japan's neighbors and the closest. However, due to Japan's compensation for the legacy of World War II this aid has at times created considerable tension and has uncovered latent anti-Japanese feeling. This dynamic has made it very difficult for Japanese aid to intervene in domestic processes in trying to promote gender issues, democracy, human rights and good governance.

Even though Japan's focus is on assisting the world's poorest countries, the amount it contributes still lags behind the overall DAC efforts. In 1991-1992, the percentage of Japan's toral ODA directed to the least developed countries (LDCs) ranked it twentieth out of 21 DAC members (Ibid., 7). In 2004-2005. Japan was still well below the median. During this time, Japan's net disbursements of ODA to LDCs were only 23 percent (Total DAC 35 percent).

TABle 7. Distribution OF ODA BY INCOME Groupio

\begin{tabular}{ccccc}
\hline Income group & $\begin{array}{c}2005 \\
\text { (Calendar year) }\end{array}$ & 2006 & 2007 & $\begin{array}{c}\text { Number of countries } \\
(2007)\end{array}$ \\
\hline LDC & $1.311 .3(12.6)$ & $1.114 .9(15.4)$ & $1.874 .8(32.4)$ & 50 \\
\hline I.ICs & $1,136.7(11.0)$ & $2.760 .2(38.0)$ & $1.067 .2(18.5)$ & 17 \\
\hline L.MICs & $6.632 .5(63.9)$ & $1.783 .9(24.6)$ & $1.336 .4(23.1)$ & 47 \\
\hline UMICs & $53.7(0.5)$ & $371.5(5.1)$ & $352.3(6.1)$ & 30 \\
\hline HICs & $0.3(0.0)$ & $0.0(-)$ & $-154.0(-)$ & 1 \\
\hline Unclassifiable & $1.250 .7(12.0)$ & $1.231 .3(17.0)$ & $1.301 .4(22.5)$ & \\
\hline Total & $10.385 .2(100.0)$ & $7.261 .8(100.0)$ & $5.778 .1(100.0)$ & \\
\hline
\end{tabular}

SOURCF: Japan's ODA W'hite Paper 2008

Even though Japan has a clear policy on focusing on Asia due to geographic, economic, historic, and cultural reasons, it is yet to develop a policy regarding poor countries or to specifically target those living in poverty. In 2001, of Japan's bilateral ODA, 16 percent went to LDCs (Total DAC 26 percent), 45 percent to Other Low Income Countries (Total DAC 33 percent), and 34 percent to Lower Middle-Income Countries (Total DAC 35 percent). Japan's disbursement to LDCs as a proportion of bilateral ODA is the fourth lowest among the DAC. The top ten recipients of Japanese ODA for 2001-2002 were China, India, Thailand, Indonesia, Philippines, Vietnam, Bangladesh, Pakistan, Sri Lanka, and Brazil; at this time only Bangladesh was an LDC (OECD 2003, 25). However, six were Low Income Countries and the list includes the world's top five countries with the most number of absolute donors from 27 countries. Among African countries, Japan was the largest donor in seven countries. Japan could further and usefully clarify its policy on how it intends to focus on poor countries or the poor populations within recipient countries. 


\section{Korea}

It is apparent that Korea has no special bilateral relationship with any developing country as a result of a former colonial relationship or global strategic objectives. Its ODA policy has been determined first by diplomatic and more recently by commercial objectives. As in the case of most "donor" countries, these objectives relate closely to Korca's national goals.

Korea's export promotion strategy has led its economy to be heavily dependent upon raw materials to produce export goods and domestic consumption from developing countries from 1970 to 1985 . With the growth of the Korean national economy and rising national income levels in the future, greater priority is expected to be given to the promotion of economic cooperation with developing countries in order to secure raw materials ( $\mathrm{Kim}$ and Seddon 2005, 162).

During the period from 1989 to 1999 , Asia was the largest recipient region of bilateral loans through the EDCF, with an average of 62 percent out of total disbursement (KOREAEXIM 2000, 38). The trend has been one of increasing regional concentration; the loans are concentrated in a small number of countries by virtue of their economic linkage with Korea and their capacity of repayment -only 24 countries have received EDCF loans since their establishment in 1987. Korea's emphasis on Asia during the 1990 s shows a pattern similar to Japan's. The decline was gradual through the 1980 s and early 1990s, reaching 54 percent in 1995. There is some evidence of an upward trend again in the second half of the 1990s (Rix 1980; Government of Korea 1992; Government of Korea 2000). As of the end of 1999, 43 percent of bilateral loans went to the other low-income countries (LICs), followed by Romania, Poland and Hungary with 21.5 percent, lower middle-income countries (LMICs) with 17 percent, least developed countries (LDCs) with 17 percent and upper middle-income countries (UMICs) with 2 percent (KOREAEXIM 2000, 38).

Table 8. Korea's BHLAteral. ODA by Region

\begin{tabular}{ccccccc}
\hline & 1996 & 2003 & 2005 & 2006 & 2007 & 2008 \\
\hline Asia & 58.1 & 78.5 & 80.9 & 60.5 & 60.8 & 52.2 \\
\hline Africa & 6.4 & 7.7 & 8.4 & 12.7 & 14.2 & 19.3 \\
\hline America & 12.1 & 4.6 & 4.3 & 6.9 & 11.1 & 12.7 \\
\hline Europe & 6.4 & 1.2 & 0.7 & 8.3 & 3.4 & 2.4 \\
\hline Unallocated & 19.8 & 6.0 & 5.5 & 11.3 & 9.7 & 13.0 \\
\hline SOURCE: KOREAEXIM & & & & & &
\end{tabular}

During the 1990s KOICA increased its focus on the Asian region. Korean resources flowing to Asia increased from 29 percent in 1991 to 65 percent 
in 1999 (KOICA 2001, 336) while the share received by Africa declined, from 31 percent to 8 percent, and Latin America's share also went down from 22 percent to 9 percent. The establishment of diplomatic relations with China, Vietnam, Cambodia and Laos contributed to this trend, with China and Vietnam emerging as the first-and second-largest beneficiaries respectively of KOICA programs. Korea's economic crisis in late 1997 awakened the government and the people of Korea to its close economic interdependence with ASEAN member countries (Ko and Lee 2008).

With respect to the allocation of Korea's bilateral ODA as a whole, in 2005, the largest share ( 57 percent) went to other LMICs, 25 percent to LDCs and 12 percent to LICs. Among total shares of bilateral ODA to LDCs, grant share was only 35 percent. In comparison with Korea, out of 22 DAC member countries, 21 provided more than 90 percent of bilateral ODA in grant form to LDCs on a 2004-2005 average commitment basis. The proportion of Japanese bilateral ODA allocated to LDCs was also low (ranging from 11 to 15.5 percent from 1989 to 1998), compared to that of other DAC member countries (OECD 2001,235 ), but, by contrast with Korea, the grant share has been above 90 percent since 1992 (Government of Korea 2000, 131).

TABLE 9. DistriBtTION OF BIIATERAL GRANTS W' INCOME Group (\%)

\begin{tabular}{|c|c|c|c|c|c|c|}
\hline & 1.DCs & I.ICs & LMICs & UMICs & $\mathrm{HICs}$ & Others \\
\hline 1991 & 32.5 & 27.0 & 28.6 & 7.2 & - & 4.7 \\
\hline 1992 & 32.7 & 21.1 & 33.9 & 7.4 & - & 5.0 \\
\hline 1993 & 30.2 & $2-1.7$ & 36.5 & 4.0 & 0.1 & 4.5 \\
\hline 199.1 & 27.3 & 33.7 & 29.8 & 3.6 & . & 5.5 \\
\hline 1995 & 25.6 & 34.4 & 30.4 & 2.8 & - & 6.9 \\
\hline 1996 & 23.0 & 35.3 & 34.2 & 3.3 & 3.9 & 4.2 \\
\hline 1997 & 20.6 & 32.5 & 39.0 & 3.7 & 3.7 & 4.2 \\
\hline 1998 & 16.9 & 32.3 & 43.5 & 2.3 & 4.5 & 5.0 \\
\hline 1999 & 13.9 & 53.7 & 27.5 & 2.3 & 2.0 & 2.7 \\
\hline 2002 & 22.1 & 21.6 & 40.4 & 10.8 & - & 5.0 \\
\hline 2003 & 23.2 & 15.8 & 53.1 & 1.8 & - & 6.0 \\
\hline 2004 & 24.4 & 14.2 & 53.1 & 1.6 & - & 6.6 \\
\hline 2005 & 24.9 & 11.4 & 57.2 & 1.0 & - & 5.5 \\
\hline 2006 & 24.5 & 12.9 & 49.4 & 1.4 &. & 11.9 \\
\hline 2007 & 24.7 & 7.6 & 51.1 & 4.4 & - & 12.1 \\
\hline 2008 & 26.8 & 12.7 & 38.5 & 5.2 & - & 16.8 \\
\hline
\end{tabular}

SOURCE: Revised from Korea International Cooperation Agency 2001; KOREAEXIM. 
The code and principle, that aid to LDCs should be provided on a grant basis, has been emphasized repeatedly on various international occasions and most donors are expected to provide grant aid to the less developed countries. Certainly, in 1992 at least, 34 LDCs together received the largest share (36.4 percent) of Korea's grant aid. There was, furthermore, considerable change during the period in the ratio of bilateral grants to income groups. In 1991, the largest share, 32.5 percent, went to LDCs, but it was down to 14 percent by 19y9 (Table 9). What was allocated previously to LDCs went mainly to LICs and LMICs. In fact, the major recipient countries belonged to these two groups.

\section{SECTORAL DISTRIBUTION}

\section{Japan}

The overreaching framework of Japanese sector priorities is set in the ODA Charter, from which a hierarchy of strategies cascade down through medium-term objectives, country programming, sector-specific initiatives, to detailed project design. The ODA Charter, in principle, shapes a new vision of Japanese sector priorities into the following issue areas:

- Poverty reduction (education, health, water and sanitation, agriculture)

- Sustainable growth (infrastructure, trade and investment)

- Global issues (environment, infectious diseases, population, food, energy, natural disaster, terrorism, drugs, organized crime)

- Peace-building (conflict prevention, emergency assistance) (OECD 2003. 28).

However, in practice, traditionally Japan has been focused on economic infrastructure and hence it still remains the main sector in the distribution of ODA. Also, three major characteristics emerged. First, the region that has been the main beneficiary of Japanese ODA has been East Asia, through the NIES, ASEAN member countries, and in China. Second, Japanese ODA has consisted of investment in the building of so-called industrial infrastructure: the gigantic structures that constitute the foundation for national economic development. Third, the capital, which requires repayment of both the principal and the interest, has consisted mostly of loans (Watanabe 2005, 17).

By comparing the sectored priorities of Japan with the ones of the DAC, we can easily identify Japan's emphasis on the economic sector. In 2001-2002, DAC on average spent 33 percent on social infrastructure and services while providing 15 percent of the ODA to economic infrastructure and services. Japan gave assistance to economic infrastructure and service up to 37 percent of the ODA while allocating 21 percent to social infrastructure and services. 
Table 10. Japan's Bilateral. ODA by Major Purposes

\begin{tabular}{|c|c|c|c|c|c|c|c|}
\hline \multirow[t]{2}{*}{ Japan } & $\begin{array}{c}1997-2001 \\
\text { average } \\
\text { Constant }\end{array}$ & \multirow[t]{2}{*}{ 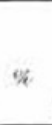 } & $\begin{array}{c}2002-2006 \\
\text { average } \\
\text { Constant }\end{array}$ & \multirow[t]{2}{*}{ \% } & \multirow[t]{2}{*}{$\begin{array}{c}2007-2008 \\
\text { average } \\
\text { Constant } \\
20(07 \text { UDS m }\end{array}$} & \multirow[t]{2}{*}{$\%$} & \multirow[t]{2}{*}{$\begin{array}{c}2007-08 \\
\text { Total DAC: } \\
\%\end{array}$} \\
\hline & 2007 UDS m & & 2007 UDS $\mathrm{m}$ & & & & \\
\hline Social infrastructurexservices & 2,475 & 21 & 2,726 & 22 & 3,122 & 22 & 41 \\
\hline Education & 793 & 7 & 926 & 7 & 709 & 5 & y \\
\hline of which basic education & 66 & 1 & 133 & 1 & 110 & 1 & 2 \\
\hline Health & 294 & 3 & 315 & 2 & 254 & 2 & 4 \\
\hline of which basic health & 81 & 1 & 100 & 1 & 168 & 1 & 3 \\
\hline $\begin{array}{l}\text { Population and reproductive } \\
\text { health }\end{array}$ & 19 & 0 & 11 & 0 & 28 & 0 & 7 \\
\hline W/ater supply and sanitation & 1.108 & 10 & 1,035 & 8 & 1,705 & 12 & 5 \\
\hline Government\&civil suciety & 97 & 1 & 267 & 2 & 268 & 2 & 13 \\
\hline $\begin{array}{l}\text { of which: Conflict, peace } \\
\text { and security }\end{array}$ & . & - & 15 & 0 & 48 & 0 & 3 \\
\hline $\begin{array}{l}\text { Other social } \\
\text { infrastructuredservices }\end{array}$ & 117 & 1 & 172 & 1 & 156 & 1 & i \\
\hline $\begin{array}{l}\text { Economic infrastructure } \\
\text { and services }\end{array}$ & 4.155 & 38 & 3.477 & 27 & 4.427 & 32 & 15 \\
\hline Transportixstorages & 2.71 & 21 & $1.5,7$ & is & 2.667 & 19 & 6 \\
\hline Communications & 191 & 2 & 1.16 & $i$ & 80 & 1 & 0 \\
\hline Energy & $1.11^{7}$ & 12 & 1.113 & 11 & 1.428 & 10 & 4 \\
\hline Banking\&financial services & 13 & 0 & 22 & 0 & 36 & 0 & 3 \\
\hline Businesswerher services & $5 x$ & 1 & 19) & 0 & 216 & 2 & 2 \\
\hline Production sectors & 1.591 & 1. & 1.030 & $\mathbf{8}$ & 1.626 & 12 & 6 \\
\hline $\begin{array}{l}\text { Agricultufe, foresery and } \\
\text { fishing }\end{array}$ & 1.1 .7 & 10 & 726 & 6 & 991 & 7 & I \\
\hline $\begin{array}{l}\text { Industry, mining and } \\
\text { construction }\end{array}$ & 101 & 3 & 168 & 1 & 578 & 1 & 1 \\
\hline Trade and tourism & 2 & 0 & 50 & 0 & (9) & 11 & 1 \\
\hline Other & 19 & 0 & 86 & 1 & 8 & 6 & 0 \\
\hline Multisector & 587 & 5 & 418 & 3 & 742 & 5 & 6 \\
\hline $\begin{array}{l}\text { Commindity and } \\
\text { programme aid }\end{array}$ & 733 & 6 & 115 & 1 & 671 & s & 5 \\
\hline Action relating to debt & 875 & 8 & 3,648 & 29 & 2,215 & 16 & 10 \\
\hline Humanitarian aid & 132 & 1 & 325 & 3 & 256 & 2 & 8 \\
\hline $\begin{array}{l}\text { Administrative costs of } \\
\text { donors }\end{array}$ & 684 & 6 & 649 & 5 & 752 & 5 & 5 \\
\hline Aid to NGOs (cure support) & 66 & 1 & 283 & 22 & 215 & 2 & 2 \\
\hline Refugees in donor contries & $\cdot$ & $\cdot$ & $\cdot$ & $\cdot$ & 1 & 0 & 2 \\
\hline Total bilateral allocable & 11,580 & 100 & 12,671 & 100 & 14,027 & 100 & 100 \\
\hline \multicolumn{8}{|l|}{ For reference } \\
\hline Total bilateral & 12.276 & 8.1 & 12,908 & 85 & 14.428 & 88 & 75 \\
\hline of which: Unallocated & $6 \% 6$ & 5 & 238 & 2 & 901 & 2 & $\mathbf{I}$ \\
\hline Total multilateral & 2.298 & 16 & 2.289 & 15 & 1.896 & 12 & 25 \\
\hline Total ODA & 14,575 & 100 & 15,198 & 100 & 16,324 & 100 & 100 \\
\hline
\end{tabular}

\section{NOTE: Commitments-Two-year averages.}

SOURCE: OECD 2010. 
Figure 2. Allocable Bilateral. ODA by Major Purposes 2007-2008

-Total DAC - Japan

Social intrasiructure and services

Economic intrastructure and services

15

32

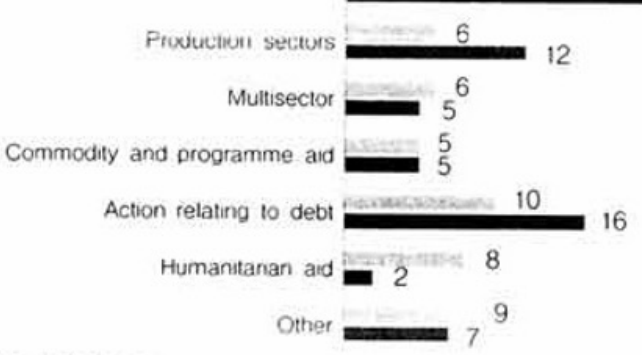

SOURCE: OECD 2010.

At the High Level Meeting in 2001, the DAC members, including Japan, resolved to ensure the centrality of sustainable poverty reduction in development cooperation, particularly at the country level. Japan was one of the promoters of the "Shaping the $21^{\text {st }}$ Century Strategy" and is also officially committed to the MDGs. At the same time, poverty reduction has yet to be treated as a central objective in the Japanese aid program, and while the MDGs are sometimes referred to, there is little correlation with projects and programs.

According to some MOFA exports, poverty reduction and MDGs are not the only concerns in development cooperation. Hence MOFA could clarify what else is important for developing countries (in peaceful situations) as well as what it means for Japan to be "committed" to poverty reduction and achieving MDGs. MOFA also mentions that countries need to "graduate" from aid dependency but does not elaborate on what that implies, especially since Japan still provides significant amounts of Official Aid to ODA graduated countries and territories such as Brunei, Hong Kong, Macao, and Singapore, in particular to Korea (OECD 2003, 31).

MOFA has been emphasizing "economic growth" or "development" more than poverty reduction. Japanese officials are proud of contributing to the growth of Asia, but rarely mention poverty reduction. The DAC Guidelines on Poverty Reduction state that economic growth is a necessary but not a sufficient condition and that supplementary measures and prerequisites are needed in order to realistically achieve the objective of poverty reduction.

\section{Korea}

In terms of sectoral distribution Korean ODA traditionally followed the same 
path of Japan, which has greatly emphasized the economic and commercial aspects aid. At the end of the 1980s, 93 percent of Korea's bilateral ODA was allocated to building economic infrastructure. Unlike other ODA member countries which put a larger share of their bilateral ODA into social-administrative and non-economic infrastructure categories, Korea has concentrated its bilateral ODA on the economic infrastructure sector. This trend is also closely related to the increase of EDCF loans for which economic considerations weigh heavily in selecting projects for support (Government of Korea 1997, 30). Since the early 1990s, small changes began to emerge; such as the adding of mining, industry and construction sectors as new categories.

Table 11. Korea's Billateral. ODA by Sector

\begin{tabular}{|c|c|c|c|c|}
\hline & 1991 & 1995 & 2005 & 2006 \\
\hline Social and administrative & 44.76 & 53.90 & 398.00 & 403.1 \\
\hline \multicolumn{5}{|l|}{ Infrastructure } \\
\hline of which Education & 16,46 & 9.50 & 50.17 & 135.2 \\
\hline Healeh & 2.36 & 5.10 & 89.64 & 38.6 \\
\hline Water supply & 1.7 .1 & 36.00 & 0.06 & 0.5 \\
\hline Population planning & 0.00 & $0.10^{*}$ & 101.56 & 80.8 \\
\hline Public administration & 7.79 & 0.80 & 72.30 & 141.6 \\
\hline Others & 0.00 & 2.40 & 84.25 & 6.5 \\
\hline \multirow{6}{*}{$\begin{array}{l}\text { Economic Infrastructure } \\
\text { of which Transport } \\
\text { Communication } \\
\text { Encrgy } \\
\text { Finance service } \\
\text { Others }\end{array}$} & 37.30 & 132.60 & 138.12 & 171.0 \\
\hline & 14.37 & 74.30 & 82.92 & 99.5 \\
\hline & 11.00 & 47.20 & 51.64 & 65.3 \\
\hline & 0.00 & 10.40 & 3.25 & 5.0 \\
\hline & & & 0.16 & 0.6 \\
\hline & 11.90 & 0.70 & 0.15 & 0.8 \\
\hline Production & 11.09 & 34.70 & 50.25 & 33.5 \\
\hline Agriculture and Fishery & 1.21 & 2.30 & 41.29 & 11.8 \\
\hline Mining, Industry and Construction & 9.89 & 27.10 & 8.22 & 17.4 \\
\hline Trade and Tourism & 0.00 & 5.20 & 0.74 & 4.3 \\
\hline \multicolumn{2}{|l|}{ Multi-sector } & & 3.88 & 9.2 \\
\hline \multicolumn{2}{|l|}{ Emergency Assistance } & & 36.87 & 24.6 \\
\hline \multicolumn{2}{|l|}{ Administrative expenses } & & 19.38 & 25.3 \\
\hline \multicolumn{2}{|l|}{ Others } & & 11.30 & 8.8 \\
\hline \multicolumn{2}{|l|}{ Total } & & 657.79 & 675.5 \\
\hline
\end{tabular}

SOURCE: Korea's bilateral ODA by Sector (www.odakorea.go.kr).

We can also witness the consistent increase in the aid for development of social infrastructure since 2000. In bilateral ODA for 2005 from Table 11, the assistance provided to social infrastructure amounts to 39.8 million USD (61 percent) leaving the aid to economic infrastructure at 13.8 million USD 
(21 percent). Among the programs of social infrastructure, water supply and sanitation are at the top of the list. The order and amount of social infrastructure aids is as follows: water supply and sanitation (11.6 million USD), health (89.6 million USD), public administration (72.3 million USD), and education ( 50.2 million USD).

Especially in grant allocation, the assistance to social infrastructure and services emphasizing human development is growing at a fast rate. Based on the principle of "selection and concentration," KOICA is narrowing down the recipient countries that qualify for grants, rather than spreading the funds across as many countries as possible, in order to maximize the effects of limited resources. After considering the degree of poverty, political situation, and the nature of the recipients' cooperative relationship with Korea, KOICA selected 18 prior partnership countries (KOICA 2006, 10).

TABLE 12. KoICA's GRANT USES HY REgION AND SECTOR 2008

\begin{tabular}{|c|c|c|c|c|c|c|c|c|}
\hline & Asi.t & Alrica & $\begin{array}{c}\text { Middle } \\
\text { East }\end{array}$ & $\begin{array}{c}\text { Central } \\
\text { and } \\
\text { south } \\
\text { America }\end{array}$ & $\begin{array}{c}\text { Eastern } \\
\text { Eur. } \\
\text { and CIS }\end{array}$ & Oceania & Others & $\begin{array}{l}\text { Total } \\
(\%)\end{array}$ \\
\hline Education & 18,216 & 8.810 & 6,134 & 2.737 & 2,611 & 22 & 0 & 15.4 \\
\hline Health & 16.567 & 10.946 & 3.331 & 8.485 & 2.465 & 1.120 & 0 & 17.3 \\
\hline Administrative institution & $11.5+3$ & 6.904 & 2.831 & +.574 & +1.275 & 477 & 0 & 12.2 \\
\hline Rural development & 12,808 & 8.510 & 220 & 2,174 & 93 & 171 & 0 & 9.6 \\
\hline Information Technology (IT) & 13.552 & 8,312 & 1.159 & 8.738 & 2.169 & 247 & 0 & 13.6 \\
\hline Industrial enctgy & $15,03.4$ & 5.601 & 971 & 2.226 & 3.101 & 83 & 0 & 10.8 \\
\hline Environment and others & 10,896 & 4,193 & 933 & 2.573 & 674 & 95 & 0 & 7.8 \\
\hline Emergency assistance & 8,411 & 1.294 & 30 & 488 & 354 & 51 & 2 & 4.2 \\
\hline Total (\%) & 42.7 & 21.8 & 6.2 & 12.8 & 6.5 & 0.9 & 9.2 & 100 \\
\hline
\end{tabular}

SOURCE: Korea International Cooperation Agency 2008.

\section{CONCLUSION}

This paper has addressed the question "in what ways are ODA policies of Japan and Korea are similar or different?" It has approached the question at many levels by examining philosophy and objectives; volume and quality; regional and sectoral allocations.

When we look at the experience of Japanese and Korean ODA policies closely, we can conclude that foreign aid began as one thing and became another. Both Japan and Korea showed that aid (for purposes other than humanitarian relief) 
began as a temporary expedient of Cold War diplomacy. It was not primarily an expression of altruism on the part of aid-giving countries. To take an upper hand in competing with North Korea during the 1970s, Korean foreign aid began as a realist response to the deepening Cold War between East and West. While continuing to be deployed in the service of national interests, Korean ODA is now moving toward the more humanitarian end of the spectrum. Since Korea has not yet developed coherent and consensus-based objectives for ODA, both inside and outside of government, it can be said to have a malleable advantage in consolidating the internationally respected practices of foreign aid, for use in the future. As long as MOFA and MOF are allowed to control the grants and loans respectively, they have shown their willingness to adjust their policy orientations to the demands of Korea NGOs. The receptivity of Korean government toward the NGO voices is very well illustrated in the recent policy dialogues.

The purposes and ideas surrounding the ODA programs of both countries might be considered to be the results of the two countries efforts to increase "soft power," which has great influence in international relations. Yet, these strategies of Korea and Japan do not seem to deviate from their pursuit of their national interest. Two underlying mainstream schools of thought supporting the rationale for ODA: one with an idealistic, humanitarian purpose, and the other with commercial, realist, political and economic purposes. These two differing rationales sometimes conflict with each other and at other times result in a compromise, combining elements of each. As discussed in this paper, Japanese aid is often regarded as motivated by primarily commercial purposes, as a vehicle for expanding Japan's exports. What was missing in much of Japan's aid was a major humanitarian focus, even after many commercial purposes have declined. In contrast to this, Korean ODA is shifting more rapidly to a more humanitarian focus. This paper argues that even though Korea and Japan share many traits in ODA polices, Korea is more likely to pursue humanitarian objectives with its ODA rather than the politico-strategic goals of Japan.

As for the organizational characteristics of aid distribution, such as fragmentation, the quality of ODA (grant rate, grant elements, and conditionality), or regional and sectoral priorities, Japan and Korea share many similar features. How can we safely forecast the future of Japan and Korea's policies? Will Korea tend to resemble Japan in its ODA policies? Or will Koreans develop so-called "Korean-style" ODA policies which will be distinct from those of their Japanese counterparts? Surely it will depend on both domestic and international factors. Subsequent research should follow closely the influence of civil society in reshaping the ODA policies of both countries. The trends toward more humanitarian justification for ODA point to an increasing role for civil society organizations in playing a larger role in setting the agenda for aid in the future. 


\section{REFERENCES}

Arase, D. 1995. Buying Power: The Political Economy of Japan's Foreign Aid. Boulder, CO: Lynne Reiner.

Cheongwadae. 2009. Global Korea: The National Security Strategy of the Republic of Korea. Cheongwadae: Republic of Korea (in Korean).

Cockcroft, James, Andre Gunder Frank, and Dale Johnson. 1972. Dependence and Underdevelopment. New York: Anchor Books.

Government of Japan. 2003. Japan's Official Development Assistance Charter. Tokyo: Economic Co-operation Bureau; Ministry of Foreign Affairs.

Government of Korea. 1989. Hand book on External Economy. Seoul: Economic Planning Board (in Korean).

1993. Report on Economic Cooperation with Developing Countries.

Seoul: Economic Planning Board (in Korean)

1997. Korea's Official Development Assistance. Seoul: Ministry of Foreign Affairs and Trade (in Korean).

2000. Korea's Official Development Assistance. Seoul: Ministry of Foreign Affairs and Trade (in Korean).

Hitoshi Tanaka, 2009. Japan's Foreign Policy and East Asian Regionalism. The Council on Foreign Relations.

Hook, W. Steven and Guang Zhang. 1998. Japan's Aid Policy since the Cold War: Rhetoric and Reality. Asian Surtey 38(11): 1051-1066.

Jun, Hwang-soo. 1995. Japan's Economic Cooperation Policy to ASEAN: ODA's Purposes and Outcomes. Korean Journal of International Studies 35(2): 291-316 (in Korean).

Jung, Chang-ho. 2005. Effects on the OECD's Regulation of Tied Aid in Korea's ODA. Workshop paper of KIEP's Professional Pool for International Economy. Seoul: Institute of Foreign Affairs and National Security (in Korean).

Katada, S. N. 2002. Japan's Two-track Aid Approach: The Forces behind Competing Triads. Asian Survey 42(2): 320-342.

Kim, H. S. 1990. On Korea's Mid-and Long-term Economic Cooperation with Developing Countries. Seoul: Korea Institute for International Economic Policy (KIEP).

Kim, S. T. and David Seddon. 2005. ODA Policy and Practice: Japan and the Republic of Korea. In Japan's Foreign Aid: Old Continuities and New Directions, eds. David Arase. New York: Routledge.

KOICA. 2001. KOICA 10-Year Review. Seoul: KOICA (in Korean). 2006. KOICA Annual Report. Seoul: KOICA (in Korean).

Ko, Kyung-min, Kim, Soon-im, and Hong, Jin-hyuk. 2010. ODA and National Interest: Implications for Korea's Sustainable ODA Development. Korea and Wolrd Politics 26(3): 95-128 (in Korean).

Kwon, Hae-ryong. 2006. Initiative of Korea for Development Cooperation: 
Development Cooperation is Our Blue Ocean. Seoul: Life and Dream (in Korean).

Lancaster, Carol. 2007. Foreign Aid: Diplomacy, Development, Domestic Politics. Princeton: Princeton University Press.

Lee, Chang-jae. 2007. Korea's Experience in Development Cooperation. Presentation paper on EDCF International Conference. Seoul: KIEP (in Korean).

Lumsdaine, H. David. 1993. Moral Vision in International Politics: the Foreign Aid Regime 1949-1989. Princeton, NJ: Princeton University Press.

Lumsdaine, David and James C. Schopf. 2007. Changing Values and the Recent Rise in Korean Development Assistance. The Pacific Review 20(2): 221-255. Morgenthau, Hans. 1962. A Political Theory of Foreign Aid. American Political Science Revietw 56(2): 301-309.

OECD. 2001. Available at http://www.oecd.org/dac/htm/agjpn.htm. 2007. The OECD International Development Statistics CD-ROM. Paris: OECD.

Park, Hong-young. 2003. Studies on the Characteristics and Change of Japanese Type of Foreign Aid Policy: Comparing Perspective on other Imperial Countries. Korean Journal of International Studies 43(4): 381-399 (in Korean).

Rix, A. 1980. Japan's Economic Aid: Policymaking and Politics. London: Croom Helm. Affairs 62(4): 461-475.

Tsukasa Takamine. 2009. Development Cooperation as a Foundation of Japan's Foreign Policy. Tokyo: Institute for International Trade and Cooperation. Wan, Ming. 1995. Spending Strategies in World Politics: How Japan Has Used Its Economic Power in the Past Decade. International Studies Quarterly 39: 85-108.

Watanabe, T. 2005. History of Japan's ODA in Brief. In Reality of Aid Asia-Pacific 2005 Report, eds. Manila Philippines: IBON Foundation, Inc.

Yasuyuki Sawada. 30 September 2010. Japan's Official Development Assistance: Basic Principle, New Changes and a Case Study of Indonesia. Presentation paper on the International Conference Organized by Korean Association of Area Studies.

Yukiko Kuramoto. 2004. Ideas and Institutions: Japan's Foreign Aid Policy. Conference Paper on the Midwest Political Science Association National Conference in Chicago.

2007. Japan's Foreign Aid Policy as a Vital Foreign Policy: Did Japan Achieve Its National Interests?. Conference Paper on the 48th Annual Convention of International Studies Association in Chicago.

Zhou, Xiaoming. 1991. Japan's Official Development Assistance Program: Pressure to Expand. Asian Survey 31(4): 341-350. 


\section{ENDNOTES}

"In this paper, "ODA" and "foreign aid" are used interchangeably, although the two terms are not exactly same. The Development Assistance Committee (DAC) of the Organization of Economic and Cooperation and Development (OECD) defines ODA as grants or loans to developing countries that are 1) undertaken by the official sector, 2) with promotion of economic development and welfare as the main objective, and 3) on concessional terms of at lest 25 percent grant element) Foreign aid, on the othet hand, has broader implications in terms of forms, vbjectives, and condiciuns of assistance. While important for some other purpose, the distinction is of little significance for the aims of this paper.

Hereafter Korea is also used for referring South Kore.

This committee, located in Prime Minister's Office, is charged with coordinating the ODA policies among various governmental agencies.

'Rix, A. 1990. Japan's Foreign Aid Policy: A Capacity for Leadership?. Pacific Affair 644): 461-475; Zhou, Xiaomin. 1991. Japan's Official Development Assistance Program: Pressure to Expand. Asian Surve 31(4), 341-350; Steven, Hook W, and Guang Zhang. 1998. Japan's Aid Policy since the Cold War: Rhetoric and Reality. Asian Surne 38(11): 1051-106; Park, Hong-young. 2003. Studies on the characteristics and change of "Japanese type" of foreign aid policy: comparing perspective on other imperial countries International Politic collection of treatise 43 . Korean international political Association: Jun, Hwang-500. 1995 Japan's Economic Cooperation Policy to ASEAN: ODA's Purposes and outcomes. International Politics collection of treatise 354 Korea's International Political Science Association.

The original Japanese ODA Charter was approved in a February 1992 cabinet decision and defined support for self-help efforts as the most important aspect of Japanese ODA Japan has pledged improvement since at least the 1992 ODA Policy Charter, and even after Jeciding to reduce its quantitative effort. Japan continues to emphasize its desire to improve the beneficial impact of its ODA. It is, therefore, of interest to see how Japan has been responding to the challenge to improve aid quality as spending decreases, and even as Japan has become more assertive regarding the use of its ODA to pursue its own national interests

"See hetp://www.odakorea.go.kr. 27 April 2011.

Grants are composed of grant aid (material assistance and projects) and technical cooperation (training. experrise sharing, and feasibility studies) programs.

EDCF is a bilateral ODA loan program established in 1987. The mapor funding source of EDCF is the government's general budget account and borrowings form the government's special budget account

The term "concessionality" mainly refers to the grant portion of the total ODA amount and grant elements in loans.

14. LDC: least developed country, LIC: low-income country, LMIC: lower middle-income country, UMIC: upper middle-income country. 